\title{
Effect of Heating Oxyhemoglobin and Methemoglobin on Microsomes Oxidation
}

Ricard Bou ${ }^{\mathrm{ab}}$, Nicolas Hanquet ${ }^{\mathrm{a}}$, Rafael Codony ${ }^{\mathrm{b}}$, Francesc Guardiola ${ }^{\mathrm{b}}$, Eric A. Decker $^{\mathrm{a}}$

a University of Massachusetts, Department of Food Science, Amherst (MA), USA

${ }^{\mathrm{b}}$ University of Barcelona, Nutrition and Food Science Department, XaRTA-INSA, Barcelona, Spain 


\section{ABSTRACT}

Different heme proteins such as hemoglobin $(\mathrm{Hb})$ have been proposed to be major prooxidants in raw and cooked meats. Despite the fact that the content of $\mathrm{Hb}$ in meat is considerable, little attention has been devoted to $\mathrm{Hb}$ in comparison to myoglobin. To understand the mechanisms and differentiate between the prooxidant and antioxidant potential of oxyhemoglobin (OxyHb) and methemoglobin (MetHb), their prooxidant activity, protein solubility, radical scavenging capacity, iron content and the relative weight of non-chelatable iron on lipid oxidation were determined as a function of thermal treatments. The ability of native $\mathrm{OxyHb}$ and $\mathrm{MetHb}$ to promote lipid oxidation was similar and higher than those $\mathrm{Hb}$ heated at 68 and $90 \mathrm{C}$ but not different from that at $45 \mathrm{C}$. However, the prooxidant activity of $\mathrm{MetHb}$ heated at 68 and $90 \mathrm{C}$ were similar whereas $\mathrm{OxyHb}$ heated at $68 \mathrm{C}$ was higher than that heated at $90 \mathrm{C}$. The decreased prooxidant activity of heat denatured $\mathrm{Hb}$ was associated with $\mathrm{a}$ decrease in the solubility of heme iron while free iron showed little impact on the lipid oxidation onset.

KEYWORDS: Oxyhemoglobin, methemoglobin, lipid oxidation, heme iron 


\section{INTRODUCTION}

Iron, copper and heme species such as hemoglobin $(\mathrm{Hb})$ and myoglobin $(\mathrm{Mb})$ contribute to lipid oxidation in different muscle-based foods (Rhee, Ziprin et al. 1987, Monahan, Crackel et al. 1993, Kanner, German et al. 1987). However, the pathways and relative importance by which all these compounds are able to initiate and propagate lipid oxidation in raw and cooked meats is still not completely understood (Baron, Andersen 2002, Johns, Birkinshaw et al. 1989, Min, Ahn 2005, Decker, Hultin 1992, Kanner 1994, Carlsen, Moller et al. 2005).

$\mathrm{Hb}$ is the major heme compound found in muscle foods from several fish species (Richards, Hultin 2002). In chicken breast, $\mathrm{Hb}$ has been reported to be the major (Kranen, Van Kuppevelt et al. 1999) or almost the unique heme pigment present (Hazell 1982) whereas in dark meat and in other different poultry species the ratio between $\mathrm{Hb}$ and $\mathrm{Mb}$ varies from $20 \%$ to $40 \%$ (Niewiarowicz, Pikul et al. 1986). In mammal species, this ratio has been reported to range from $7 \%$ to 35\% (Hazell 1982, Oellingrath, Iversen et al. 1990, Han, Mcmillin et al. 1994). Therefore, even though the $\mathrm{Hb}$ content can vary a lot among animal species and muscle types, it is clear that the $\mathrm{Hb}$ levels present in muscle-based foods have the potential to substantially contribute to lipid oxidation (Alvarado, Richards et al. 2007).

$\mathrm{Hb}$ consists of four globular protein subunits and each contains one heme group. Heme groups consist of an iron atom contained in the center of a large heterocyclic organic ring called porphyrin which can be bound tightly to heme proteins like $\mathrm{Hb}$. $\mathrm{Hb}$ can be in the ferrous form with (OxyHb) or without $(\mathrm{DeoxyHb})$ the presence of oxygen and can autooxidize to the ferric form (MetHb). The presence of oxygen and other ligands in the $\mathrm{Hb}$ cause conformational changes that have been reported to promote oxidation differently (Richards, Dettmann 2003). 
The formation of ferryl and/or perferryl species upon reaction with hydrogen peroxide or lipid hydropexides has been reported to be either truly initiators or important catalysts of lipid oxidation in raw muscle meat products (Kanner, German et al. 1987, Baron, Andersen 2002, Kanner, Harel 1985). Various factors such as the ability of the $\mathrm{Hb}$ to autoxidize and release of hematin, the heme-iron moiety non-bound to the protein, have also been reported to be crucial in promoting lipid oxidation (Richards, Dettmann 2003, Grunwald, Richards 2006a, Richards, Dettmann et al. 2005).

Upon cooking, there is an increased susceptibility to oxidation, however; the explanation for that phenomenon has not been completely elucidated. Several factors such as the release of hematin from $\mathrm{Hb}$ and iron from the porphyrin moiety and from other proteins such as ferritin and transferrin have been reported in meats (Monahan, Crackel et al. 1993, Grunwald, Richards 2006a, Han, Mcmillin et al. 1995). However, heating treatments provoke protein precipitation an this loss of solubility has been reported to be determinant for $\mathrm{Mb}$ in inhibiting oxidation (Bou, Guardiola et al. 2008). In addition, denaturation may cause conformational changes increasing or decreasing the exposure of different amino acids. This different exposure can influence the ability of proteins to chelate prooxidants and scavenge free radicals thus affecting the antioxidantprooxidant balance of food products (Elias, Kellerby et al. 2008).

Therefore, in proteins like $\mathrm{Hb}$, which has been reported to promote oxidation, it is important to study the possible mechanisms by which native and denatured $\mathrm{Hb}$ are able to promote oxidation in order to develop strategies to efficiently inhibit oxidative rancidity. In this frame, the aim of this work was to determine how denaturation of $\mathrm{Hb}$ at different temperatures changes its prooxidative activity and antioxidative properties in a muscle microsome membrane model system.

\section{MATERIAL AND METHODS}


Reagents and standards. $\mathrm{Hb}$ from bovine blood, fluorescein sodium salt, ethylenediaminetetraacetic acid (EDTA) disodium salt dihydrate, 2-thiobarbituric acid (TBA), 1,1,3,3-Tetraethoxypropane (TEP), L-ascorbic acid, ferrous sulfate heptahydrate, 2,2'-azobis(2-methylpropionamidine) dihydrochloride (AAPH), nitrilotriacetate, hydroxylamine hydrochloride, butylated hydroxytoluene (BHT) and 3-(2-pyridyl)-5,6-bis(4-phenylsulfonic acid)-1,2,4-triazine (ferrozine) were from Sigma-Aldrich Co (St. Louis, MO). Potassium chloride, sodium nitrite, sodium phosphate dibasic and monobasic, hydrochloric acid, ammonium acetate and sodium hydrosulfite were obtained form Fisher-Scientific (Pittsburgh, PA). Trichloroacetic (TCA) anhydride, ferric chloride and acetone were from Acros Organics (Fair Lawn, NJ). The chemicals used for the Lowry method (Lowry, Rosebrough et al. 1951) were of ACS grade.

Preparation of microsomes. Pork tenderloin muscle microsomes were isolated according to the method of Brannan and Decker (Brannan, Decker 2001). Frozen pork was diced into approximately $0.5 \mathrm{~mm}$ cubes and then chopped in a stainless steel blender for $1 \mathrm{~min}$, and the resulting paste $(25 \mathrm{~g})$ was homogenized in $90 \mathrm{~mL}$ of $0.12 \mathrm{M} \mathrm{KCl} / 25 \mathrm{mM}$ phosphate buffer, $\mathrm{pH} 7.2$, in a tissuemizer (20000 rpm; Tekmar, Cincinnati, OH) for $2 \mathrm{~min}$, followed by centrifugation for 30 min at $10000 \mathrm{~g}$ at $4 \mathrm{C}$ (Sorvall Ultra 80, DuPont, Wilmington, DE). The resulting supernatant was ultracentrifuged for $60 \mathrm{~min}$ at $100000 \mathrm{~g}$ to pellet insoluble muscle components including the microsomes. Myofibrillar proteins were then solubilized from the pellet in $0.6 \mathrm{M} \mathrm{KCl} / 25 \mathrm{mM}$ phosphate buffer, $\mathrm{pH} 7.2$, and a microsome-containing pellet was isolated by centrifugation for $60 \mathrm{~min}$ at 100000 g. Isolated microsomes were standardized to $30 \mathrm{mg}$ of protein / $\mathrm{mL}$ of $0.12 \mathrm{M}$ / $25 \mathrm{mM}$ phosphate buffer, $\mathrm{pH} 7.2$, and stored at $-80 \mathrm{C}$ until use. Protein in the microsomal fraction was determined by using the method of Lowry et al. (Lowry, Rosebrough et al. 1951). 
Preparation of Oxy and Methemoglobin. A commercial $\mathrm{Hb}$ stock solution was prepared by weighing $0.16 \mathrm{~g}$ of $\mathrm{Hb}$ standard dissolved in $3 \mathrm{~mL}$ cold phosphate buffer $(50 \mathrm{mM}, \mathrm{pH}=7.3)$ and kept at $4 \mathrm{C}$.

The stock solution of $\mathrm{Hb}$ was chemically reduced to $\mathrm{OxyHb}$ by mixing with sodium hydrosulfite (ratio $1: 0.9 \mathrm{w} / \mathrm{w}$ ) and allowed to react for $10 \mathrm{~min}$ at $4 \mathrm{C}$. Another $\mathrm{Hb}$ stock solution was fully oxidized to MetHb by mixing potassium ferricyanide $(2.3 \%)$ and allowed to react for $5 \mathrm{~min}$ at $4 \mathrm{C}$. Then, the excess of sodium hydrosulfite or potassium ferricyanide were removed by passing each solution through an Econo-Pac 10 DG disposable desalting column (Bio-Rad Laboratories, Hercules, CA; exclusion limit $6000 \mathrm{Da}$ ) as follows. Each $\mathrm{Hb}$ solution $(3 \mathrm{~mL})$ was layered onto the column and allowed to pass into the column bed. Then, $4 \mathrm{~mL}$ of phosphate buffer was passed into the stationary phase to elute the respectively $\mathrm{Hb}$ out of the column. In a 1:50 dilution kept at $4 \mathrm{C}$ the DeoxyHb, $\mathrm{OxyHb}$ and $\mathrm{MetHb}$ ratios were calculated as reported elsewhere (Benesch, Benesch et al. 1973) by measuring the absorbance at 560, 576 and $630 \mathrm{~nm}$ using a Shimadzu UV-visible scanning spectrophotometer model UV-2101PC (Shimadzu Scientific Instruments, Columbia, MD). Only those solutions containing a minimum yield of $90 \%$ of $\mathrm{OxyHb}$ or MetHb conversion were used.

Then, the freshly prepared $\mathrm{OxyHb}$ and $\mathrm{MetHb}$ desalted solutions were adjusted to $\mathrm{pH}=5.6$ and diluted to the final $\mathrm{Hb}$ required concentration according to the Snell-Marini equation (Snell, Marini 1988) by measuring the absorbance at 523 $\mathrm{nm}$ (isobestic point). Those fresh solutions were capped and placed in a water bath set at $25 \mathrm{C}$, and water bath was set to $90 \mathrm{C}$. When the temperature of the water bath reached 45, 68 and $90 \mathrm{C}$ tubes were immediately taken out and kept on ice. Samples were used the same day as preparation except for samples used for ORAC assay and heme and nonheme iron analyses which were immediately stored at $-80 \mathrm{C}$ until use. 
Measurement of lipid oxidation. A solution containing $\mathrm{Hb}$ and microsomes (final concentrations $0.08 \mathrm{~g} / \mathrm{dL}$ and $9 \mathrm{mg}$ protein $/ \mathrm{mL}$, respectively) dissolved in 50 $\mathrm{mM}$ phosphate buffer, $\mathrm{pH}=5.6$ were mixed and incubated for different periods at $37 \mathrm{C}$ in a water bath under gentle agitation.

Lipid oxidation was monitored by measuring thiobarbituric acid reactive substances (TBARS) by means of a modified procedure described elsewhere (Bou, Guardiola et al. 2008). Briefly, at each incubation time, $1 \mathrm{~mL}$ of the mixture of microsomes plus $\mathrm{Hb}$ was mixed with $1 \mathrm{~mL}$ of a TBA solution containing $20 \%$ TCA, $0.5 \%$ TBA, $0.2 \%$ EDTA and $30 \mathrm{mM} \mathrm{HCl}$ in screw capped tubes. Immediately after, $30 \mu \mathrm{L}$ of $3 \% \mathrm{BHT}$ in ethanol was added and tubes were then closed and vortexed. Subsequently, samples were heated in a boiling water bath for $15 \mathrm{~min}$, cooled at room temperature, and centrifuged at $1750 \mathrm{~g}$ for $20 \mathrm{~min}$. The absorbance of the supernatant was measured at $532 \mathrm{~nm}$, and the results were reported as micromoles of malondialdehyde (MDA) per $\mathrm{kg}$ of microsomal protein. Concentrations were determined from a MDA standard curve produced from TEP.

UV-Visible spectrophotometry of heated myoglobin. Samples of appropriately diluted $\mathrm{Hb}$ solutions ( $50 \mathrm{mM}$ phosphate buffer, $\mathrm{pH}$ 5.6) were placed in the thermoblock of an Ultrospec 3000 Pro model spectrophotometer (Biochrom Ltd., Cambridge, UK). The thermoblock was equilibrated at $25 \mathrm{C}$ and programmed at a heating rate of $0.8 \mathrm{C} / \mathrm{min}$ up to $97 \mathrm{C}$. The absorbance was recorded at $290 \mathrm{~nm}$, to monitor changes in tryptophan (Trp) absorbance.

Protein solubility. Solubility of native $\mathrm{Hb}$ and heated $\mathrm{Hb}$ was determined after centrifugation of samples at $1750 \mathrm{~g}$ for $10 \mathrm{~min}$ and then determining the protein content of the supernatant fraction by the Lowry method (Lowry, Rosebrough et al. 1951). 
Iron content. The content of heme and non-heme iron was determined in the whole $\mathrm{Hb}$ solutions and in the $\mathrm{Hb}$ supernatant fractions which were obtained after centrifugation at $1750 \mathrm{~g}$ for $10 \mathrm{~min}$.

Heme concentrations were determined using the acidified acetone extraction method of Hornsey (Hornsey 1956) with slight modifications. Five hundred $\mu L$ of the samples were added to $2.5 \mathrm{~mL}$ of acetone and $125 \mu \mathrm{L}$ of $3 \mathrm{~N} \mathrm{HCl}$. After $1 \mathrm{hr}$ at room temperature samples were centrifuged at $1750 \mathrm{~g}$ for $20 \mathrm{~min}$. The absorbance of this supernantant was measured and heme content was calculated using a molar extinction coefficient of $4800 \mathrm{M}^{-1} \mathrm{~cm}^{-1}$ at $640 \mathrm{~nm}$ for chlorohemin.

A slightly modified method described by Rhee and Ziprin (Rhee, Ziprin 1987) was used to measure non-heme iron. One hundred $\mu \mathrm{L}$ of sodium nitrite $(0.16 \% \mathrm{w} / \mathrm{v})$ and $1.5 \mathrm{~mL}$ of extraction solution $(6 \mathrm{~N} \mathrm{HCl}$ plus $40 \% \mathrm{TCA}$ in equal volumes) were added to screw-cap tubes containing $500 \mu \mathrm{L}$ of $\mathrm{Mb}$ samples. The tubes were closed, mixed and incubated in a water bath at $65 \mathrm{C}$ for $20 \mathrm{hr}$. After cooling, the mixtures were centrifuged at $1750 \mathrm{~g}$ for $10 \mathrm{~min}$ and the supernatants were passed through $0.45 \mu \mathrm{m}$ filters. To one $\mathrm{mL}$ of each filtrate, $1 \mathrm{~mL}$ of $0.8 \%$ ascorbic acid was added and the samples were allowed to stand for $15 \mathrm{~min}$. Then, $1 \mathrm{~mL}$ of $16 \%$ ammonium acetate and $1 \mathrm{~mL}$ of $0.8 \mathrm{mM}$ ferrozine were added and the absorbance at $562 \mathrm{~nm}$ was measured after 10 minutes. Concentrations were obtained using a standard curve from 0 to $2 \mathrm{mg}$ of iron / $\mathrm{L}$ produced from ferric chloride.

Oxidative capacity of non-chelatable iron. Native or heated $\mathrm{Hb}$ solutions $(0.16 \mathrm{~g} / \mathrm{dL})$ with or without added EDTA $(1.8 \mathrm{mM})$ dissolved in $50 \mathrm{mM}$ phosphate buffer $(\mathrm{pH}=5.6)$ were mixed with equal volumes of microsomes $(10 \mathrm{mg}$ protein $/ \mathrm{mL}, \mathrm{pH}=5.6$ ) and incubated for $8 \mathrm{hr}$ at $37 \mathrm{C}$ in a water bath under gentle agitation. Subsequently, the lipid oxidation was monitored by measuring TBARS as described previously and results were expressed as follows: 


$$
\frac{\left(\mathrm{x}_{\mathrm{i}}-\overline{\mathrm{x}}_{\text {EDTA }}\right)}{\overline{\mathrm{X}}_{\text {no EDTA }}} \times 100
$$

where $x_{i}$ are the different TBARS amounts found in samples without added EDTA, $\xi_{\text {EDTA }}$ is the average of TBARS amounts from those samples in which EDTA has been added and $\xi_{\text {no EDTA }}$ is the average of TBARS amounts from those samples in which EDTA has not been added. All TBARS amounts were expressed as micromoles of MDA per $\mathrm{kg}$ of microsomal protein.

Oxygen Radical Absorbance Capacity (ORAC). A 500 mM solution of AAPH in $75 \mathrm{mM}$ potassium phosphate buffer at $\mathrm{pH} 7.0$ was prepared for each experiment and kept on ice. Fluorescein was dissolved to a concentration of 50 $\mathrm{nM}$ in phosphate buffer containing $0.1 \mathrm{mM}$ EDTA before each set of experiments. For each run, fluorescein was equilibrated to $37^{\circ} \mathrm{C}$ in a water bath for $15 \mathrm{~min}$. Reagents were added in the order of native $\mathrm{Hb}$ or heated $\mathrm{Hb}$ in $75 \mathrm{mM}$ phosphate buffer ( $\mathrm{pH} 7.0$ ), fluorescein and AAPH at a final concentration of $6 \mu \mathrm{M}$, $45 \mathrm{nM}$ and $20 \mathrm{mM}$, respectively. Fluorescence was recorded from 0 to $50 \mathrm{~min}$ every $10 \mathrm{~min}$ by taking $4 \mathrm{~mL}$ aliquots in which $40 \mu \mathrm{L}$ of $500 \mathrm{mM}$ ascorbic acid was added to stop the reaction followed by centrifugation for $10 \mathrm{~min}$ at $1750 \mathrm{~g}$. The fluorescence (excitation $=493 \mathrm{~nm}$, emission $=515 \mathrm{~nm}$; Hitachi F-2000 flourometer, Tokyo, Japan) of the supernatants were measured at $37 \mathrm{C}$. The ORAC values of the $\mathrm{Hb}$ or heated $\mathrm{Hb}$ were calculated using the area under the curve (AUC) which was calculated as follows:

$$
\mathrm{AUC}=\sum_{\mathrm{i}=0}^{\mathrm{i}=\mathrm{n}} \frac{\mathrm{F}_{\mathrm{i}}}{\mathrm{F}_{0}}
$$

where $F_{0}$ is the initial fluorescence reading and $F_{i}$ is the fluorescence reading at time i.

Statistical analyses. All samples were measured in triplicate. A 1-way analysis of variance (ANOVA) was used to determine whether the heating temperature affect protein solubility, the different iron contents, the AUC values obtained from the ORAC assay and the oxidative capacity of non-chelatable iron of each $\mathrm{Hb}$. 
By taking into consideration each incubation time, a 1-way ANOVA was carried out to study whether the heating temperatures affected the pro-oxidant activity of $\mathrm{OxyHb}$ and MetHb. When ANOVAs indicated temperature effects, means were separated by the Scheffé's test. In all cases, $P \leq 0.05$ was considered significant.

\section{RESULTS}

Changes in protein properties as a result of heating. The Tryp band absorbance $(290 \mathrm{~nm})$ of $\mathrm{OxyHb}$ and $\mathrm{MetHb}$ showed similar profiles with the difference that the profile of $\mathrm{OxyHb}$ was slightly shifted to higher temperatures (Figure 1) which is in agreement with the reported lower thermal stability of oxidized heme forms (Wittung-Stafshede 1999). In both cases, conformational changes started to occur at temperatures higher than $55 \mathrm{C}$. The Tryp absorbance increased rapidly in $\mathrm{OxyHb}$ and $\mathrm{MetHb}$ at temperatures higher than $60 \mathrm{C}$ indicating that both $\mathrm{Hb}$ were unfolded at these temperatures.

The maximum unfold for MetHb occurred at $69 \mathrm{C}$ whereas the maximum for $\mathrm{OxyHb}$ was reached at $72.5 \mathrm{C}$. After their respectively maximums, the absorbance rapidly decreased until both $\mathrm{Hb}$ were completely denatured. Several authors reported differences in the prooxidant capacity of Mb heated at several temperatures (Kristensen, Andersen 1997, Berisha, Endo et al. 2000) thus, according to these profiles, we decided to compare the prooxidant and antioxidant activity of $\mathrm{OxyHb}$ and $\mathrm{MetHb}$ at 4 temperatures according to their conformational changes (native, $45 \mathrm{C}, 68 \mathrm{C}$ and $90 \mathrm{C}$ ).

Changes in protein solubility provide valuable information occurred on conformational changes. $\mathrm{OxyHb}$ and $\mathrm{MetHb}$ either native or heated at $45 \mathrm{C}$ showed no differences whereas those heated at $68 \mathrm{C}$ showed lower solubility confirming that some denaturation had occurred at this temperature (Table 1). Heating at higher temperatures led to much lower protein solubility which 
indicated extensive protein aggregation and precipitation. This explains the lowered absorbance recorded at $290 \mathrm{~nm}$ when $\mathrm{Hb}$ was heated at high temperatures.

OxyHb and MetHb on microsomes oxidation. To study the pro-oxidant activity of $\mathrm{Hb}$, this was added into microsomes to an $\mathrm{Hb} /$ protein ratio similar to that found in meats. The ability of $\mathrm{OxyHb}$ in the presence of microsomes to promote oxidation showed no differences after $2 \mathrm{hr}$ of incubation whereas the blank containing only $\mathrm{OxyHb}$ showed lower and steady TBARS values over time (Figure 2). After $4 \mathrm{hr}$ of incubation, $\mathrm{OxyHb}$ heated at $90 \mathrm{C}$ recorded lower TBARS values than native $\mathrm{OxyHb}$ whereas the other heating treatments showed no differences on microsomes lipid oxidation when compared with native $\mathrm{Hb}$ or $\mathrm{Hb}$ heated at $90 \mathrm{C}$ (Figure 2). Native $\mathrm{OxyHb}$ and $\mathrm{OxyHb}$ heated at $45 \mathrm{C}$ showed the same capacity in promoting oxidation after $\geq 8 \mathrm{hr}$ of incubation whereas the prooxidant activity of $\mathrm{OxyHb}$ heated at $68 \mathrm{C}$ was significantly lower. With the exception of the blank, $\mathrm{OxyHb}$ heated at $90 \mathrm{C}$ showed the lowest prooxidant activity.

As for MetHb, TBARS values of the blank were lower than those containing microsomes over time (Figure 3). Differences between heating treatments were observed after $6 \mathrm{hr}$ of incubation. At this time, MetHb heated at $90 \mathrm{C}$ showed lower TBARS values than the other MetHb heated below this temperature (Figure 3). Native MetHb and that heated at $45 \mathrm{C}$ showed higher oxidation values after $\geq 8 \mathrm{hr}$ of incubation whereas MetHb heated at $68 \mathrm{C}$ and $90 \mathrm{C}$, which had a similar ability to oxidation, recorded lower TBARS values.

Some controversy exists about whether the heme or free iron from both $\mathrm{Mb}$ and $\mathrm{Hb}$ is the major responsible for lipid oxidation in cooked meats (Johns, Birkinshaw et al. 1989, Grunwald, Richards 2006a, Han, Mcmillin et al. 1995, Schricker, Miller 1983). In order to a better understanding we conducted a trial in which $\mathrm{OxyHb}$ and $\mathrm{MetHb}$ either native or heated were incubated for $8 \mathrm{hr}$ at $37 \mathrm{C}$ 
in the presence of microsomes with or without added EDTA. The relative percentage of the microsomes oxidation caused by non-chelatable iron is shown in Table 1. Results indicated that the addition of EDTA provoked a relative decrease in TBARS values (10-12 \%) when OxyHb was heated at temperatures $\geq 68 \mathrm{C}$. However, the addition of the chelator almost had no effect when heated at lower temperatures.

The ability to promote oxidation of native MetHb was almost unaffected by the addition of EDTA which indicated that the chelatable iron almost had no effect on microsomes oxidation (Table 1). However, when MetHb was heated at any studied temperature, TBARS values were decreased (11-17\%). This reduction indicates that, in heated MetHb, chelatable but especially non-chelatable iron participated on microsomes oxidation.

Iron and heme content as a result of heating. The heme content was measured in the whole sample and in the supernatant fraction obtained after centrifugation. Therefore, results provided valuable information about the destruction of the porphyrin ring as a consequence of the thermal treatments and the distribution of the heme iron. In the whole samples, $\mathrm{OxyHb}$ and $\mathrm{MetHb}$ heme iron content showed no significant differences between treatments (Table 1). However, differences in the heme iron content were recorded in the supernatant fraction. OxyHb heated at $45 \mathrm{C}$ showed no differences for the heme content in the supernatant fraction in comparison to native $\mathrm{OxyHb}$ but above this temperature the heme content was lowered as temperature increased (Table 1). Similar trends were observed for MetHb although MetHb heated at $68 \mathrm{C}$ did not show a different heme content in the supernatant fraction compared with MetHb heated at $45 \mathrm{C}$ or at $90 \mathrm{C}$ (Table 1).

The non-heme iron content indicates those changes in the free iron fraction that can occur for instance because of the iron release from $\mathrm{Hb}$. In the whole sample, no differences were recorded as a consequence of heating for $\mathrm{OxyHb}$ and $\mathrm{MetHb}$ 
(Table 1) which was in agreement with the fact that the porphyrin ring structure had not been destroyed. In the supernatant fraction, OxyHb showed no changes in the non-heme iron content with temperature. Conversely, the non-heme iron content in the supernatant fraction of $\mathrm{MetHb}$ heated at $90 \mathrm{C}$ and $68 \mathrm{C}$ was decreased in comparison to native and that heated at $45 \mathrm{C}$ (Table 1). This decrease in the water soluble nonheme iron content suggests that the pool of free iron was bound to $\mathrm{Hb}$ and thus removed upon precipitation of the protein.

OxyHb and MetHb antioxidant capacity. The ORAC assay showed that native $\mathrm{OxyHb}$ and that heated at $45 \mathrm{C}$ had a higher antioxidant activity than $\mathrm{OxyHb}$ heated at $68 \mathrm{C}$ which in turn was higher than that heated at $90 \mathrm{C}$ (Table 1). Likewise, MetHb heated at $90 \mathrm{C}$ showed lower antioxidant capacity than the other MetHb treatments. The overall decrease of the antioxidant capacity of the $\mathrm{Hb}$ as a consequence of heating was likely due to a lower exposure of amino acids with radical scavenging capacity (Elias, Kellerby et al. 2008).

\section{DISCUSSION}


$\mathrm{Mb}$ and $\mathrm{Hb}$ have been reported to promote lipid oxidation in muscle based foods (Baron, Andersen 2002, Kanner, Harel 1985, Grunwald, Richards 2006a, Richards, Dettmann et al. 2005). The ability of $\mathrm{Mb}$ and $\mathrm{Hb}$ to promote oxidation is attributed to their heme group so the oxidation mechanisms are common although subject to several conditions that may result in enhancement or decrease of their prooxidative activity (Carlsen, Moller et al. 2005).

A faster autooxidation rate and low hematin affinity, which is increased in ferric heme forms, have been related with the increase of the lipid oxidation onset (Richards, Dettmann et al. 2005, Grunwald, Richards 2006b, Richards, Nelson et al. 2007). As for autoxidation, a series of reactions can be set (Carlsen, Moller et al. 2005, Richards, Dettmann 2003, Gorelik, Kanner 2001, Yusa, Shikama 1987):

$$
\begin{aligned}
& \mathrm{OxyHb}(\mathrm{II}) \mathrm{O}_{2} \rightarrow \operatorname{DeoxyHb}(\mathrm{II})+\mathrm{O}_{2} \\
& \operatorname{DeoxyHb}(\mathrm{II})+\mathrm{O}_{2} \rightarrow \mathrm{MetHb}(\mathrm{III})+\mathrm{O}_{2}^{\cdot-} \\
& \mathrm{O}_{2}^{\cdot--}+\mathrm{O}_{2}^{\cdot-} \rightarrow \mathrm{H}_{2} \mathrm{O}_{2}+\mathrm{O}_{2}
\end{aligned}
$$

The reaction [1] is not favorable since the OxyHb is more stable than DeoxyHb but once it is formed it autoxidizes rapidly in the presence of oxygen (Richards, Dettmann 2003). Therefore, that limited reaction may explain the delayed pattern in microsomes oxidation when comparing native $\mathrm{OxyHb}$ and $\mathrm{MetHb}$ (Figures 2 and 3) whereas the formation of hydrogen peroxide [3] and the presence of lipid hydroperoxides led to the formation of ferryl $(\mathrm{Hb}(\mathrm{IV})=\mathrm{O})$ and perferryl $\left(\mathrm{Hb}^{\bullet}(\mathrm{IV})=\mathrm{O}\right)$ species which are efficient promoters of lipid oxidation (Baron, Andersen 2002, Kanner, Harel 1985). This hydrogen peroxide formation might explain why the oxidation values found in microsomes were slightly higher in the presence of $\mathrm{OxyHb}$. In addition, the allosterism of $\mathrm{Hb}$ upon deoxygenation and reduction may provoke that the catalytically active heme groups in the $\mathrm{OxyHb}$ were less exposed to their surroundings or more loosely in comparison to $\mathrm{MetHb}$ thus explaining those differences in the prooxidant activity. 
Heating can also favor hematin release from $\mathrm{Hb}$ which is insoluble in water. Because of that and unless it remained attached to the protein while this is soluble, this fact should provoke a decrease of the heme iron content in the supernatant fraction. Heating $\mathrm{Hb}$ at $45 \mathrm{C}$ seemed to have no effect on heme group insolubilization or destruction although a slight decrease was observed for $\mathrm{MetHb}$ (Table 1). This temperature is just before some changes in the Tryp band were observed (Figure 1) which was in agreement with the lack of effect on protein solubility and antioxidant capacity measured through ORAC values. All these observations were in agreement with the recorded lack of effect on the susceptibility to oxidation after heating $\mathrm{Hb}$ at $45 \mathrm{C}$ in comparison with their respective native $\mathrm{Hb}$ (Figures 2 and 3 ).

The increased heme moiety exposure reported after protein unfolding as a consequence of heating at a moderate/high temperatures (60-70 C) (Kristensen, Andersen 1997) and the release of hematin (Grunwald, Richards 2006a) and iron (Decker, Hultin 1992) from $\mathrm{Mb}$ and $\mathrm{Hb}$ at higher temperatures have been indicated as major causes of the increased susceptibility to oxidation in cooked meats. In our conditions, heme and non-heme iron content results indicated that the iron-porphyrin moiety was quite resistant to thermal treatments even when heated at $90 \mathrm{C}$ (Table 1) which was also in agreement with other works (Bou, Guardiola et al. 2008, Kristensen, Andersen 1997, Han, Mcmillin et al. 1993). However, heme iron contents were decreased in the supernatant fractions as thermal treatment increased (Table 1). Unfortunately, from our results it is not possible to know whether the heme moiety is completely released, in the form of hematin, or not since heme iron precipitation was concomitant with the protein solubility.

By looking at TBARS values and heme iron content in the supernatant fraction it was observed that they were related since the addition of $\mathrm{OxyHb}$ heated at $68 \mathrm{C}$ into microsomes led to intermediate values for both susceptibility to oxidation and heme content (Table 1 and Figure 2). Similarly, there were no differences 
between MetHb heated at 68 and that heated at $90 \mathrm{C}$ for both parameters (Table 1 and Figure 3). This fact supports the hypothesis that $\mathrm{Hb}$, which precipitated and aggregated upon heating, cocooned the catalitically active heme iron since both the heme moiety and heme crevice are hydrophobic. Therefore, in case that the heme moiety was located inside the aggregate, it could only interact with the denatured $\mathrm{Hb}$ and would explain the poor prooxidant effect when different heated $\mathrm{Hb}$ were added into the microsomes mixture. This relationship between heme iron loss of solubility and prooxidant activity has been reported previously in Mb (Bou, Guardiola et al. 2008, Berisha, Endo et al. 2000).

Because of the low affinity to water, hematin easily associates to different components present in the media such as bovine serum albumin and membrane components (Ledward 1971, Everse, Hsia 1997, Avissar, Shaklai et al. 1984). Therefore, either the direct interaction with membranes rich in polyunsatured lipids or through other proteins present in media will likely serve to shuttle hematin to membranes and, in consequence, favor the increased susceptibility to oxidation in cooked meats. Grunwald et al. (Grunwald, Richards 2006a) also suggested this hypothesis after they observed that lipid oxidation was promoted in washed cod muscle when hematin was added together with bovine serum albumin. However, this mechanism was impeded in our model system since $\mathrm{Hb}$ was precipitated before adding to microsomes thus explaining the differences in the prooxidative activity of heated heme proteins among studies.

Amino acids, peptides and proteins have been reported to act as antioxidants due to its ability in scavenging free radicals and chelating prooxidative metals (Elias, Kellerby et al. 2008, Chan, Decker 1994). Changes in the exposure of some amino acids could be related with the more maintained antioxidant capacity of MetHb in comparison to OxyHb when they were heated (Table 1). This effect was correlated with the overall poor prooxidant activity of heated $\mathrm{Hb}$. Protein denaturation could also have increased the exposure of amino acid residues such as histidine, glutamic acid and aspartic acid known to bind metals and/or 
hinder iron from the surface (Elias, Kellerby et al. 2008). The likely decreased exposure of some amino acid residues of the MetHb might explain the lowered non-heme iron content in the supernatant found in MetHb heated at $68 \mathrm{C}$ and 90 C (Table 1). This explanation about iron encapsulation is in agreement with a previous work that reported a lowered iron release after dialysis when Mb was at heated at $100 \mathrm{C}$ in comparison to that heated at $74 \mathrm{C}$ (Berisha, Yasushi et al. 2003).

Regardless of the heating temperature, the latter authors also found that the released iron was responsible for only $20 \%$ of the prooxidant activity compared with the $\mathrm{Mb}$ itself when after heating this was added to a media containing linoleic acid (Berisha, Yasushi et al. 2003). In order to evaluate the impact of free iron versus heme on lipid oxidation, we added to the microsome solution native and heated $\mathrm{Hb}$ either with or without added EDTA. Results showed that chelatable iron had a low impact in the promotion of lipid oxidation in native $\mathrm{Hb}$ proteins thus indicating that oxidation was only due to its catalytic activity rather than free iron (Table 1). In heated OxyHb, the non-heme content in the supernatant was constant with temperature but only about $10-12 \%$ of the oxidation could be attributed to the effect of the free iron. This indicated that heme iron, in the native form or as in other heat-denatured heme forms, was the main responsible of the oxidation. MetHb heated at $90 \mathrm{C}$ showed the maximum percent $(17 \%)$ of lipid oxidation reduction which could be due to the low net prooxidant activity and low heme content in the supernatant of this heated MetHb rather than the free iron release since this was decreased in comparison to native MetHb.

Collectively, these results indicated that the content in heme iron in the supernatant largely influenced the susceptibility to oxidation whereas the free iron content had little effect. Because of its hydrophobicity, the porphyrin group seemed to be hidden inside the $\mathrm{Hb}$ denatured aggregate thus provoking the reduced susceptibility to oxidation in our system. Future works should approach 
those factors that can affect the delivery of heme groups to different targets susceptible to oxidize. Nevertheless, other factors such the ability of the different denatured $\mathrm{Hb}$ to chelate iron and the free radical scavenging capacity also determine the overall antioxidant pro-oxidant balance.

\section{Acknowledgements}

The authors thank the Fulbright Commission in Spain and The Secretary of State for Universities and Research of the Spanish Ministry of Education and Science for their financial support. 


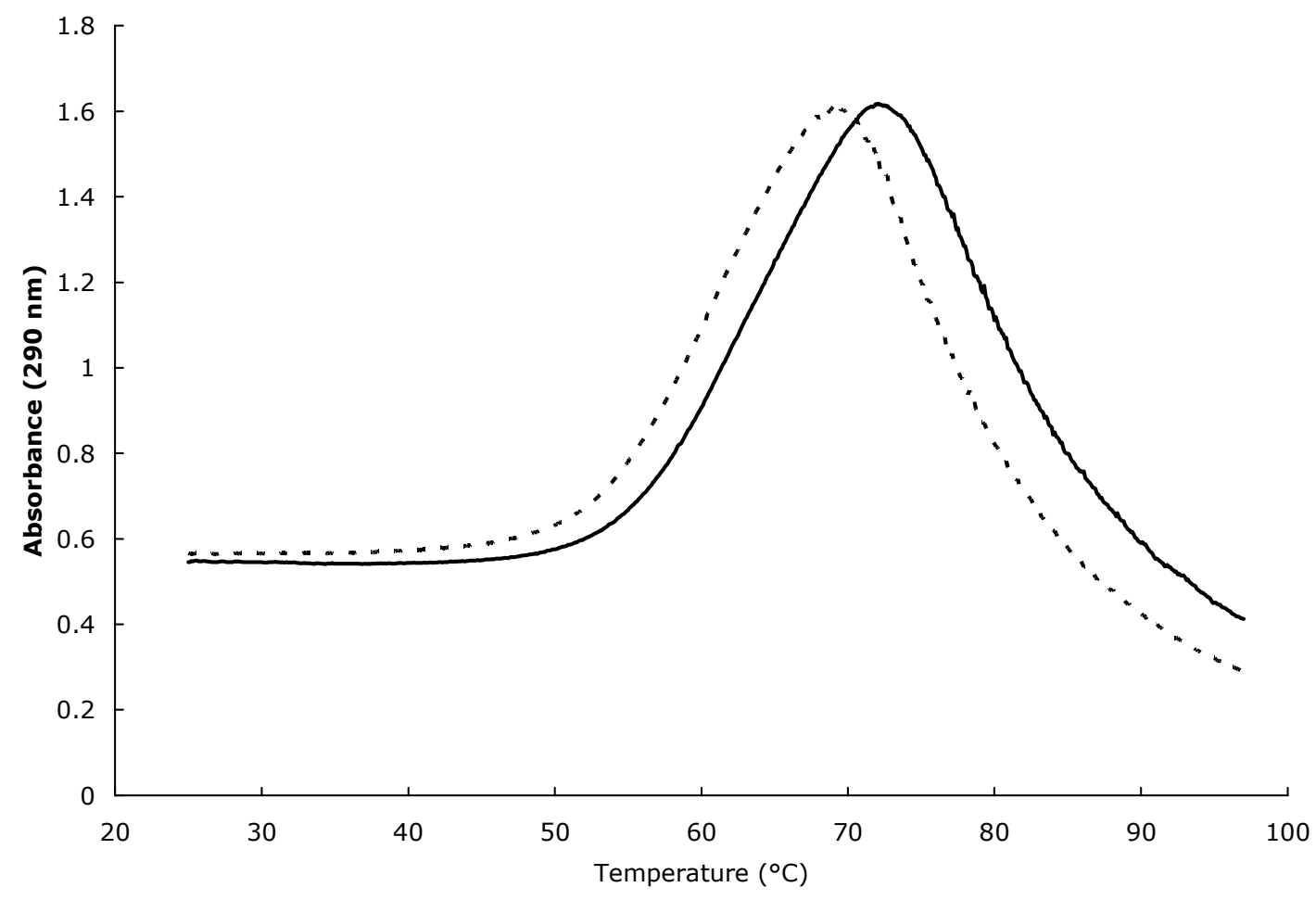

Figure 1. Absorbance changes of oxyhemoglobin (solid line) and methemoglobin (dashed line) solutions $(0.04 \mathrm{~g} / \mathrm{dL} ; \mathrm{pH}=5.6)$ at $290 \mathrm{~nm}$ with a heating rate of 0.8 $\mathrm{C} / \mathrm{min}$. 


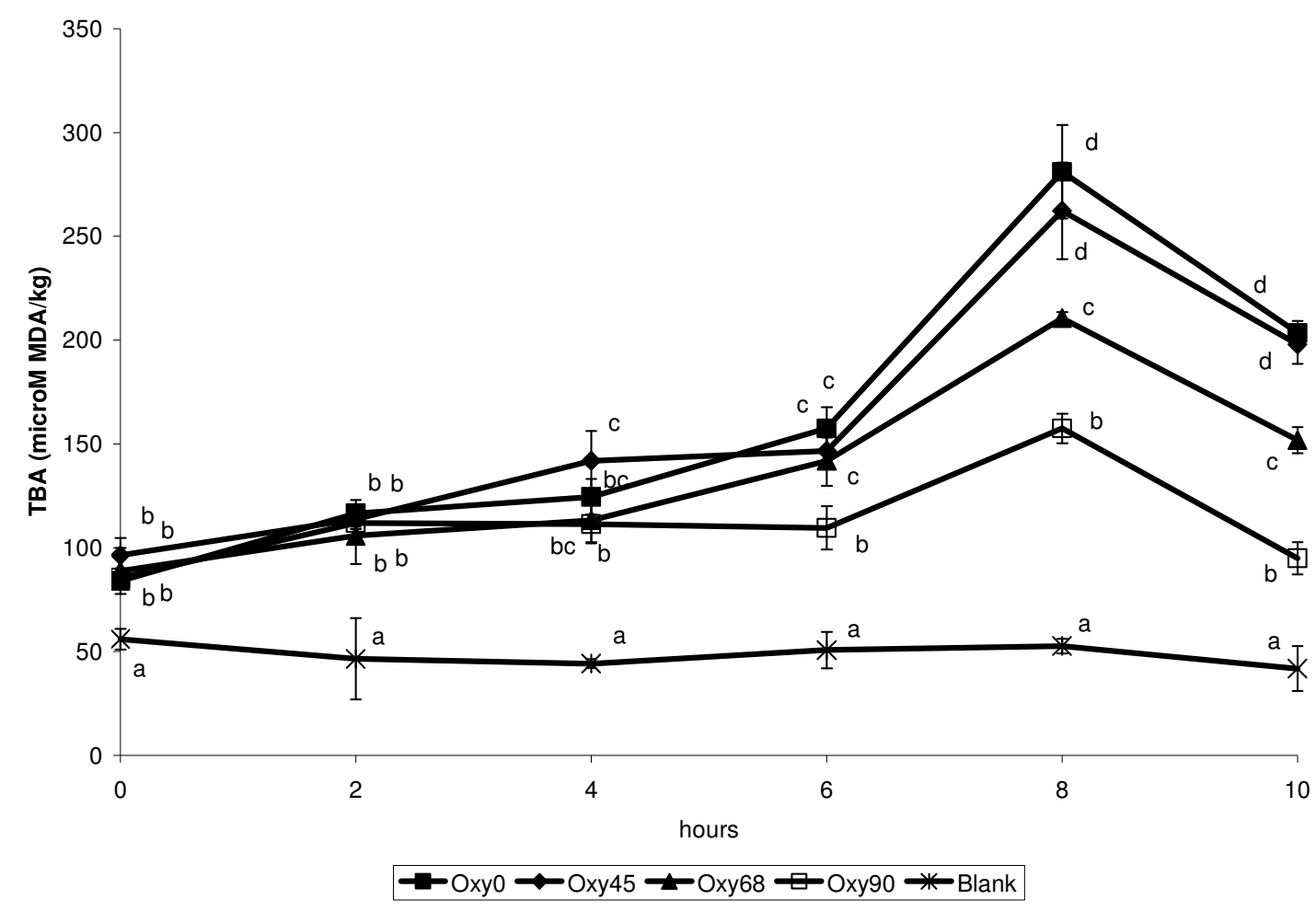

Figure 2. Effect of oxyhemoglobin (final concentration $0.08 \mathrm{~g} / \mathrm{dL}$ ) heated at different temperatures on the formation of thiobarbituric acid reactive substances (TBA; $\mu$ mols MDA $/ \mathrm{kg}$ protein) in the presence of muscle microsomes (final concentration $9 \mathrm{mg} / \mathrm{mL}$ ) at $37 \mathrm{C}$ for different incubation times. Blank correspond to samples made with native oxyhemoglobin. For each incubation time, values corresponding to a certain variable with different letter differ significantly $(P \leq$ 0.05). 


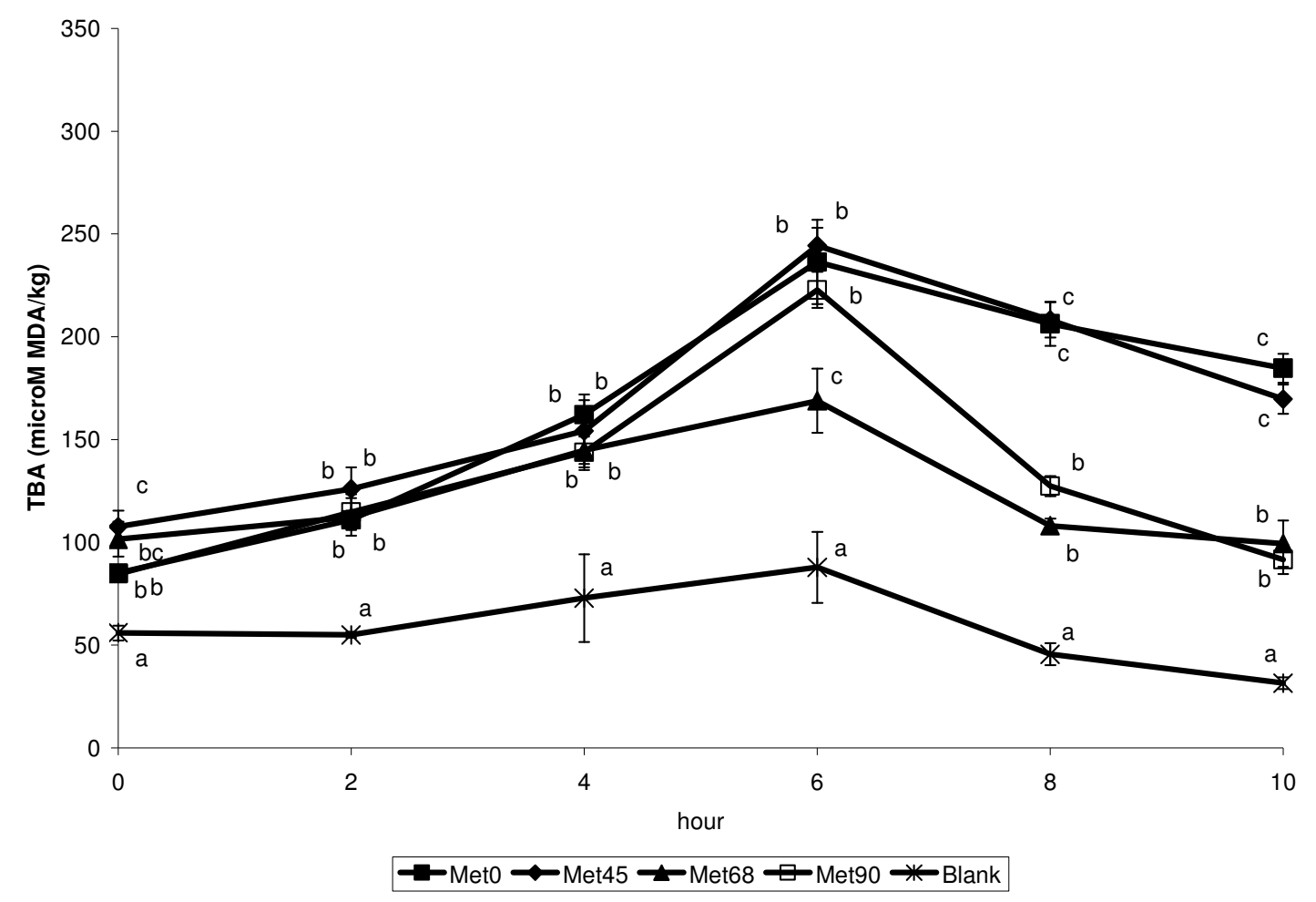

Figure 3. Effect of methemoglobin (final concentration $0.08 \mathrm{~g} / \mathrm{dL}$ ) heated at different temperatures on the formation of thiobarbituric acid reactive substances (TBA; $\mu$ mols MDA $/ \mathrm{kg}$ protein) in the presence of muscle microsomes (final concentration $9 \mathrm{mg} / \mathrm{mL}$ ) at $37 \mathrm{C}$ for different incubation times. Blank correspond to samples made with native methemoglobin. For each incubation time, values corresponding to a certain variable with different letter differ significantly $(P \leq$ 0.05). 
Table 1. Effect of heating oxyhemoglobin and methemoglobin on protein solubility, radical scavenging capacity, oxidative capacity of non-chelatable iron, heme and non-heme content in either the whole sample or in the supernatant after centrifugation ${ }^{1}$.

\begin{tabular}{|c|c|c|c|c|c|c|c|}
\hline $\begin{array}{l}\text { Heating } \\
\text { temperature } \\
\text { (C) }\end{array}$ & $\begin{array}{c}\text { Protein } \\
\text { solubility } \\
\text { (mg/L) }\end{array}$ & $\begin{array}{l}\text { Radical } \\
\text { scavenging } \\
\text { capacity } \\
(A \cup C)^{2}\end{array}$ & $\begin{array}{l}\text { Heme in } \\
\text { whole } \\
\text { sample } \\
\text { (microM) }\end{array}$ & $\begin{array}{c}\text { Heme in the } \\
\text { supernatant } \\
\text { (microM) }\end{array}$ & $\begin{array}{c}\text { Non- } \\
\text { heme in } \\
\text { whole } \\
\text { sample } \\
\text { (microM) }\end{array}$ & $\begin{array}{l}\text { Non-heme } \\
\text { in the } \\
\text { supernatant } \\
\text { (microM) }\end{array}$ & $\begin{array}{c}\text { Oxidative } \\
\text { capacity } \\
\text { of non- } \\
\text { chelatable } \\
\text { iron } \\
(\%)\end{array}$ \\
\hline & \multicolumn{7}{|c|}{ OxyHemoglobin } \\
\hline Native & $971 \mathrm{a}$ & $3.61 \mathrm{a}$ & $35 a$ & $35 a$ & $105 a$ & $64 a$ & $0.3 a$ \\
\hline 45 & $956 \mathrm{a}$ & $3.67 \mathrm{a}$ & $31 \mathrm{a}$ & $34 \mathrm{a}$ & $106 a$ & $78 \mathrm{a}$ & $3.9 \mathrm{a}$ \\
\hline 68 & $515 b$ & $2.59 \mathrm{~b}$ & $32 \mathrm{a}$ & $20 \mathrm{~b}$ & $86 a$ & $63 \mathrm{a}$ & $10.5 \mathrm{~b}$ \\
\hline 90 & $12 \mathrm{c}$ & $1.82 \mathrm{c}$ & $33 a$ & $6 \mathrm{c}$ & $93 a$ & $50 a$ & $11.9 \mathrm{~b}$ \\
\hline \multirow[t]{2}{*}{$\mathrm{SE}^{3}$} & 9.9 & 0.089 & 1.7 & 2.4 & 9.5 & 9.4 & 0.74 \\
\hline & \multicolumn{7}{|c|}{ MetHemoglobin } \\
\hline Native & $868 a$ & $3.49 \mathrm{a}$ & $30 a$ & $31 a$ & $112 \mathrm{a}$ & $94 a b$ & $3.3 a$ \\
\hline 45 & $864 a$ & $3.81 \mathrm{a}$ & $30 a$ & $26 a b$ & $89 a$ & $124 \mathrm{a}$ & $11.7 \mathrm{~b}$ \\
\hline 68 & $468 \mathrm{~b}$ & $3.38 \mathrm{a}$ & $26 a$ & $13 \mathrm{bc}$ & $108 a$ & $69 \mathrm{~b}$ & $14.5 \mathrm{~b}$ \\
\hline 90 & $10 \mathrm{c}$ & $2.35 \mathrm{~b}$ & $26 \mathrm{a}$ & $0.4 \mathrm{c}$ & $92 \mathrm{a}$ & $58 \mathrm{~b}$ & $17.1 \mathrm{~b}$ \\
\hline SE & 10.0 & 0.15 & 3.1 & 2.7 & 6.4 & 7.2 & 1.4 \\
\hline
\end{tabular}

\footnotetext{
Values correspond to means obtained from an ANOVA $(n=12)$. Means corresponding to a certain variable and for each level of certain hemoglobin bearing no common letters are statistically different $(P \leq 0.05)$.

${ }^{2}$ The radical scavenging capacity was calculated using the area under the curve of the oxygen radical absorbance capacity (ORAC) assay.

${ }^{3}$ SE means the standard error which is formed by dividing the pooled standard deviation by the square root of the number of observations at each level.
} 


\section{REFERENCES}

ALVARADO, C.Z., RICHARDS, M.P., O'KEEFE, S.F. and WANG, H., 2007. The effect of blood removal on oxidation and shelf life of broiler breast meat. Poultry science, 86(1), pp. 156-161.

AVISSAR, N., SHAKLAI, M. and SHAKLAI, N., 1984. The Interaction of Hemin with Skeletal-Muscle Actin. Biochimica et biophysica acta, 786(3), pp. 179-187. BARON, C.P. and ANDERSEN, H.J., 2002. Myoglobin-induced lipid oxidation. A review. J.Agric. Food Chem., 50(14), pp. 3887-3897.

BENESCH, R.E., BENESCH, R. and YUNG, S., 1973. Equations for the spectrophotometric analysis of hemoglobin mixtures. Analytical Biochemistry, 55(1), pp. 245-248.

BERISHA, A., ENDO, Y. and FUJIMOTO, K., 2000. The effect of heating temperature on the prooxidant and hydroperoxide decomposition activity of myoglobin. Food science and technology research, 6(4; 4), pp. 257-262.

BERISHA, A., YASUSHI, E. and FUJIMOTO, K., 2003. The effect of heatinduced structural changes on the prooxidant activity of myoglobin. Italian Journal of Food Science, 15(1), pp. 85-94.

BOU, R., GUARDIOLA, F., CODONY, R., FAUSTMAN, C., ELIAS, R.J. and DECKER, E.A., 2008. Effect of Heating Oxymyoglobin and Metmyoglobin on the Oxidation of Muscle Microsomes. Journal of Agricultural and Food Chemistry, 56(20), pp. 9612-9620.

BRANNAN, R.G. and DECKER, E.A., 2001. Peroxynitrite-induced oxidation of lipids: Implications for muscle foods. J.Agric. Food Chem., 49(6), pp. 3074-3079. CARLSEN, C.U., MOLLER, J.K.S. and SKIBSTED, L.H., 2005. Heme-iron in lipid oxidation. Coordination Chemistry Reviews, 249(3-4), pp. 485-498.

CHAN, K.N. and DECKER, E.A., 1994. Endogenous skeletal muscle antioxidants. Crit.Rev.Food Sci.Nutr., 34(4), pp. 403-426.

DECKER, E.A. and HULTIN, H.O., 1992. Lipid Oxidation in Muscle Foods Via Redox Iron. ACS Symp.Ser., 500, pp. 33-54.

ELIAS, R.J., KELLERBY, S.S. and DECKER, E.A., 2008. Antioxidant activity of proteins and peptides. Crit.Rev.Food Sci.Nutr., 48, pp. 1-13.

EVERSE, J. and HSIA, N., 1997. The toxicities of native and modified hemoglobins. Free Radical Biology and Medicine, 22(6), pp. 1075-1099.

GORELIK, S. and KANNER, J., 2001. Oxymyoglobin oxidation and membranal lipid peroxidation initiated by iron redox cycle. J.Agric. Food Chem., 49(12), pp. 5939-5944.

GRUNWALD, E.W. and RICHARDS, M.P., 2006a. Mechanisms of heme proteinmediated lipid oxidation using hemoglobin and myoglobin variants in raw and heated washed muscle. J.Agric.Food Chem., 54(21), pp. 8271-8280. 
GRUNWALD, E.W. and RICHARDS, M.P., 2006b. Studies with myoglobin variants indicate that released hemin is the primary promoter of lipid oxidation in washed fish muscle. J.Agric. Food Chem., 54(12), pp. 4452-4460.

HAN, D., MCMILLIN, K.W. and GODBER, J.S., 1994. Hemoglobin, Myoglobin, and Total Pigments in Beef and Chicken Muscles - Chromatographic Determination. Journal of Food Science, 59(6), pp. 1279-1282.

HAN, D., MCMILLIN, K.W., GODBER, J.S., BIDNER, T.D., YOUNATHAN, M.T. and HART, L.T., 1995. Lipid Stability of Beef Model Systems with Heating and Iron Fractions. Journal of Food Science, 60(3), pp. 599-603.

HAN, D., MCMILLIN, K.W., GODBER, J.S., BIDNER, T.D., YOUNATHAN, M.T., MARSHALL, D.L. and HART, L.T., 1993. Iron Distribution in Heated Beef and Chicken Muscles. J.Food Sci., 58(4), pp. 697-700.

HAZELL, T., 1982. Iron and Zinc-Compounds in the Muscle Meats of Beef, Lamb, Pork and Chicken. Journal of the science of food and agriculture, 33(10), pp. 1049-1056.

HORNSEY, H.C., 1956. The color of cooked cured pork. I. Estimation of the nitric oxide/heme pigments. J.Sci.Food Agric., 7, pp. 534-540.

JOHNS, A.M., BIRKINSHAW, L.H. and LEDWARD, D.A., 1989. Catalysts of Lipid Oxidation in Meat-Products. Meat Sci., 25(3), pp. 209-220.

KANNER, J., 1994. Oxidative Processes in Meat and Meat-Products - Quality Implications. Meat Sci., 36(1-2), pp. 169-189.

KANNER, J., GERMAN, J.B. and KINSELLA, J.E., 1987. Initiation of lipid peroxidation in biological systems. Critical reviews in food science and nutrition, 25(4), pp. 317-364.

KANNER, J. and HAREL, S., 1985. Initiation of Membranal Lipid-Peroxidation by Activated Metmyoglobin and Methemoglobin. Arch.Biochem.Biophys., 237(2), pp. 314-321.

KRANEN, R.W., VAN KUPPEVELT, T.H., GOEDHART, H.A., VEERKAMP, C.H., LAMBOOY, E. and VEERKAMP, J.H., 1999. Hemoglobin and myoglobin content in muscles of broiler chickens. Poultry science, 78(3), pp. 467-476.

KRISTENSEN, L. and ANDERSEN, H.J., 1997. Effect of heat denaturation on the pro-oxidative activity of metmyoglobin in linoleic acid emulsions. J.Agric.Food Chem., 45(1), pp. 7-13.

LEDWARD, D.A., 1971. Nature of Cooked Meat Hemoprotein. J.Food Sci., 36(6), pp. 883-\&.

LOWRY, O.H., ROSEBROUGH, N.J., FARR, A.L. and RANDALL, R.J., 1951.

Protein measurement with the Folin phenol reagent. J.Biol.Chem., 193(1), pp.

265-275.

MIN, B. and AHN, D.U., 2005. Mechanism of lipid peroxidation in meat and meat products - A review. Food Sci.Biotechnol., 14(1), pp. 152-163.

MONAHAN, F.J., CRACKEL, R.L., GRAY, J.I., BUCKLEY, D.J. and MORRISSEY, P.A., 1993. Catalysis of lipid oxidation in muscle model systems by haem and inorganic iron. Meat Science, 34(1), pp. 95-106.

NIEWIAROWICZ, A., PIKUL, J. and CZAJKA, P., 1986. Myoglobin and haemoglobin content in the meat of different types of poultry. Fleischwinschaft, 66(8), pp. 1281-1282. 
OELLINGRATH, I.M., IVERSEN, A. and SKREDE, G., 1990. Quantitative determination of myoglobin and haemoglobin in beef by high-performance liquid chromatography. Meat Science, 28(4), pp. 313-320.

RHEE, K.S. and ZIPRIN, Y.A., 1987. Modification of the Schricker Nonheme Iron Method to Minimize Pigment Effects for Red Meats. J.Food Sci., 52(5), pp. 11741176.

RHEE, K.S., ZIPRIN, Y.A. and ORDONEZ, G., 1987. Catalysis of Lipid Oxidation in Raw and Cooked Beef by Metmyoglobin-H2O2, Nonheme Iron, and EnzymeSystems. J.Agric.Food Chem., 35(6), pp. 1013-1017.

RICHARDS, M.P. and DETTMANN, M.A., 2003. Comparative analysis of different hemoglobins: Autoxidation, reaction with peroxide, and lipid oxidation. Journal of Agricultural and Food Chemistry, 51(13), pp. 3886-3891. RICHARDS, M.P., DETTMANN, M.A. and GRUNWALD, E.W., 2005. Prooxidative characteristics of trout hemoglobin and myoglobin: A role for released heme in oxidation of lipids. J.Agric.Food Chem., 53(26), pp. 10231-10238.

RICHARDS, M.P. and HULTIN, H.O., 2002. Contributions of blood and blood components to lipid oxidation in fish muscle. Journal of Agricultural and Food Chemistry, 50(3), pp. 555-564.

RICHARDS, M.P., NELSON, N.M., KRISTINSSON, H.G., MONY, S.S.J., PETTY, H.T. and OLIVEIRA, A.C.M., 2007. Effects of fish heme protein structure and lipid substrate composition on hemoglobin-mediated lipid oxidation. Journal of Agricultural and Food Chemistry, 55(9), pp. 3643-3654.

SCHRICKER, B.R. and MILLER, D.D., 1983. Effects of Cooking and Chemical Treatment on Heme and Non-Heme Iron in Meat. J.Food Sci., 48(4), pp. 1340-\&. SNELL, S.M. and MARINI, M.A., 1988. A convenient spectroscopic method for the estimation of hemoglobin concentrations in cell-free solutions. Journal of Biochemical and Biophysical Methods, 17(1), pp. 25-34.

WITTUNG-STAFSHEDE, P., 1999. Effect of redox state on unfolding energetics of heme proteins. Biochimica Et Biophysica Acta-Protein Structure and Molecular Enzymology, 1432(2), pp. 401-405.

YUSA, K. and SHIKAMA, K., 1987. Oxidation of oxymyoglobin to metmyoglobin with hydrogen peroxide: Involvement of ferryl intermediate. Biochemistry, 26(21), pp. 6684-6688. 